\title{
Pathogenesis of Alcoholic Liver Disease-Recent Advances
}

\author{
Amin A. Nanji, Grace L. Su, Michael Laposata, and Samuel W. French
}

\begin{abstract}
The article summarizes the proceedings of a symposium on recent advances in research on the pathogenesis of alcoholic liver disease at the 2001 RSA meeting in Montreal, Canada. The chairs were Amin A. Nanji and Samuel W. French. The presentations were (1) Role of inflammatory mediators in alcoholic liver injury by Amin A. Nanji, (2) Role of endotoxin, lipopolysaccharide binding protein, CD14 and Toll receptors in alcoholic liver injury by Grace Su, (3) Fatty acid ethyl esters: toxicity, metabolism and markers of ethanol intake by Michael Laposata, and (4) Cyclic changes in gene expression when rats are fed alcohol at a constant rate by Samuel W. French.
\end{abstract}

Key Words: Alcoholic Liver Disease, Cyclooxygenase, Lipopolysaccharide, Fatty Acid Esters, Oxidative Stress.

\section{INTRODUCTION}

\section{Amin A. Nanji}

A number of factors are important in the pathogenesis of alcoholic liver injury. These factors include endotoxin, cytokines and other proinflammatory mediators, oxidative stress and immunologic mechanisms. The mechanisms involved in alcoholinduced liver injury are not completely understood and are the subject of investigation in a number of laboratories. Studies reported here summarize some of areas of research that may help explain the consequences of alcohol intake.

\section{ROLE OF INFLAMMATORY MEDIATORS IN ALCOHOLIC LIVER INJURY}

\section{Amin A. Nanji}

Recently, there has been an explosion of knowledge about inflammatory mediators that are involved in the pathogenesis of alcoholic liver disease. However, it is not clear as yet how this work will influence our understanding of the pathogenesis of alcoholic liver disease or its treatment. For example, evidence has accumulated that Kupffer cells are an important source of inflammatory mediators and inhibition of Kupffer cell function leads to amelioration of alcoholic liver injury. Also, TNF- $\alpha$ released by Kupffer cells is important in liver regeneration.

From the Department of Pathology and Center for the Study of Liver Diseases (AAN), The University of Hong Kong and Queen Mary Hospital, Hong Kong; Department of Medicine (GLS), University of Michigan Medical Center, Ann Arbor, Michigan; Division of Laboratory Medicine, Department of Pathology (ML), Massachusetts General Hospital and Harvard Medical School, Boston, MA; Department of Pathology (SWF), Harbor - UCLA Medical Center, Torrance, $C A$.

Received for publication February 7, 2002; accepted March 6, 2002.

Supported by Grant DK 53296 from the National Institutes of Health (to $G L S)$.

Reprint requests: Amin A. Nanji, MD, Clinical Biochemistry Unit, LG 136, Block K, Queen Mary Hospital, 102 Pokfulam Road, Hong Kong; Fax: (852) 2855-9915; E-mail: ananji@pathology.hku.hk

Copyright (C) 2002 by the Research Society on Alcoholism.
One major mediator of the effects of endotoxin and oxidative stress is nuclear factor kappa B (NF- $\kappa$ B). NF- $\kappa$ B is a ubiquitous transcription factor that is implicated in the activation of several genes involved in inflammation. $\mathrm{NF}-\kappa \mathrm{B}$ is sequestered in the cytoplasm through its interaction with $\mathrm{I} \kappa \mathrm{B}$ proteins. Activation of NF- $\kappa \mathrm{B}$ occurs in rats fed ethanol intragastrically in association with endotoxemia, increased oxidative stress and liver injury (Nanji et al., 1999). Monocytes from patients with alcoholic hepatitis also display greater NF- $\kappa$ B activity than monocytes from control subjects (Hill et al., 2000). Although NF- $\kappa$ B is a potential target for treatment of inflammatory liver injury, it should be noted that inhibition of NF- $\kappa \mathrm{B}$ can initiate fulminant hepatic failure (Beg and Baltimore, 1998).

Among the genes activated by NF- $\kappa \mathrm{B}$ is cyclooxygenase- 2 (Cox-2) (Nanji et al., 1999). An important pivotal observation linking Cox-2 to hepatocellular injury is the study by Dinchuk et al. (1995) in Cox-2 deficient mice. Cox-2 deficient mice sensitized to TNF- $\alpha$-induced hepatotoxicity with D-galactosamine are protected against liver injury. In ethanol-fed rats, increased expression of Cox-2, mainly in Kupffer cells, is associated with endotoxemia, oxidative stress and pathologic liver injury (Nanji et al., 1997). These studies suggest a role for both Cox- 2 and TNF- $\alpha$ in promoting alcoholic liver injury. The importance of TNF- $\alpha$ and Cox- 2 in promoting liver injury is further supported by studies in female rats fed fish oil and dextrose (Nanji et al., 2001). Male and female rats fed fish oil and dextrose show increased expression of TNF- $\alpha$, but only female rats have increased expression of Cox-2 and show evidence of liver injury.

\section{ROLE OF ENDOTOXIN, LBP, CD14, AND TOLL RECEPTORS IN ALCOHOLIC LIVER INJURY}

\section{Grace $\mathrm{Su}$}

Multiple lines of evidence support the hypothesis that endotoxin or lipopolysaccharide (LPS) is an important cofactor in the pathogenesis of liver injury. This has been best delin- 
eated in alcohol-induced liver injury. In the Tsukomoto and French model of alcoholic liver disease, there is a strong correlation between the degree of liver injury and endotoxemia (Nanji et al., 1993). The pathway by which LPS contributes to liver injury is postulated to be via Kupffer cell activation. Located in the sinusoidal space, Kupffer cells are in contact with portal blood which drains the intestinal tract. They are thus exposed to bacteria and bacterial products, such as LPS, which traverse the intestinal barrier. Kupffer cells are important in clearing LPS but its interactions with LPS are not limited to clearance. Kupffer cells, when exposed to LPS, can be activated to produce a spectrum of cytokines and reactive oxygen intermediates. These inflammatory mediators, such as TNF- $\alpha$, can contribute to further liver injury. In human alcoholic hepatitis, elevations of TNF- $\alpha$ are associated with a worse prognosis (Felver et al., 1990) and treatments such as corticosteroids and pentoxifylline which can diminish immune activation have been shown to have some benefit. In rodent models of alcoholic hepatitis, an important role for TNF- $\alpha$ in mediating liver injury has been provided by in vivo studies using anti-TNF- $\alpha$ antibodies and TNF receptor 1 knockout mice (Iimuro et al., 1997; Yin et al., 1999). A role for Kupffer cell activation in this pathway is supported by studies showing significantly less liver injury in the presence of antibiotics, lactobacillus, or gadolinium chloride (Adachi et al., 1995); (Adachi et al.,1994); (Nanji et al., 1994).

Despite its importance, the mechanism by which LPS activates Kupffer cells is not entirely clear. In peripheral blood monocytes, LPS activation is mediated through LPS binding protein (LBP) and CD14. In serum, LPS binds to LBP, a $60 \mathrm{kDa}$ glycoprotein produced predominantly by the liver and secreted in serum (Schumann et al., 1990; Wright et al., 1990). LBP catalyzes the transfer of LPS to cell surface receptors such as membrane CD14 (Hailman et al., 1994) which shuttles it to the downstream receptor, toll-like receptor 4 (TLR4). In the presence of LBP, markedly less LPS is needed to activate peripheral blood monocytes. The LBP and CD14/TLR4 pathway is critical for interactions at the low concentrations of LPS found under physiologic conditions. We have previously shown that LBP and CD14 are increased in alcohol-induced liver injury and appear to correlate with the degree of liver injury (Su et al., 1998). Because Kupffer cells have relatively low baseline expression of CD14 (Takai et al., 1997; Ziegler-Heitbrock and Ulevitch 1993), some have suggested that Kupffer cells may behave differently from peripheral blood monocytes in regards to LPS. Furthermore, Kupffer cells and other macrophages can interact with LPS in a serum-independent fashion (Lichtman et al., 1998; Bellezzo et al., 1996). This has led some to suggest that Kupffer cell activation by LPS is mediated not through the LBP/CD14/TLR4 pathway but rather through some less well characterized pathways (Lichtman et al., 1998; Bellezzo et al., 1996).

$\mathrm{Su}$ et al., present data showing the role of LBP, CD14 and TLR4 in Kupffer cell activation (Su et al., 2000; Su et al., 2002). Using primary cultures of isolated Kupffer cells, they demonstrated that isolated Kupffer cells express both mCD14 and TLR4 receptors. Kupffer cells were then incubated with varying concentrations of LPS for $6 \mathrm{hr}$ in the presence and absence of recombinant LBP. The supernatant was then measured for TNF- $\alpha$ as a marker of Kupffer cell activation. Isolated Kupffer cells produce little baseline TNF- $\alpha$. In the presence of increasing concentrations of LPS, more TNF- $\alpha$ was produced. TNF- $\alpha$ was produced in response to LPS irrespective of the presence of LBP; however, at low concentrations of LPS ( 1 and $10 \mathrm{ng} / \mathrm{ml})$, significantly more TNF- $\alpha$ was produced in the presence of LBP. A functional role for CD14 and TLR4 in mediating Kupffer cell activation was demonstrated using CD14 deficient and TLR4 mutant animals. Kupffer cells isolated from CD14-deficient or TLR4 mutant $(\mathrm{C} 3 \mathrm{H} / \mathrm{HeJ})$ animals produced little TNF- $\alpha$ in response to LPS both in the presence and absence of LBP, suggesting that both LBPdependent and independent pathways of LPS activation occur via this critical receptor pathway. The role of CD14 in Kupffer cell activation was further supported using human Kupffer cells and well characterized anti-CD14 monoclonal antibodies. Isolated human Kupffer cells respond to LPS in a dosedependent manner which was blocked in the presence of the inhibitory anti-CD14 antibody, MY4, but not in the presence of LeuM3, an antibody which recognizes CD14, but does not block cellular activation by LPS.

The bioactivity of LBP is determined by its concentration. At low concentrations, LBP augments Kupffer cell activation but at high concentrations, this biological activity is not present. In the presence of higher concentrations of LBP, which might be seen in the acute phase response, the ability of LBP to augment phagocytosis of Gram-negative bacteria remains intact. To examine the role of LBP in liver injury, LBP knockout and wildtype animals were given an intraperitoneal injection of carbon tetrachloride and liver histology examined. At day 1, both LBP knockout and wildtype animals had significant liver necrosis due to the $\mathrm{CCl}_{4}$. However, by day 5, LBP wildtype animals had histologic improvement while LBP knockout animals continued to have significant necrosis. This suggests a protective role of LBP in the pathogenesis of $\mathrm{CCl}_{4}$-induced liver injury. The mechanism for this protection is a subject of ongoing research. However, this data supports the hypothesis that endotoxin and mediators of endotoxin-induced cellular activation such as LBP, CD14 and TLR4 play a role in the pathogenesis of liver injury.

\section{FATTY ACID ETHYL ESTERS: TOXICITY, METABOLISM, AND MARKERS OF ETHANOL INTAKE}

\section{Michael Laposata}

Fatty acid ethyl esters (FAEE) are nonoxidative metabolites of ethanol. The synthesis of fatty acid ethyl esters in vivo is poorly understood as many diverse enzymes have been identified as contributory to the synthesis of fatty acid ethyl esters from ethanol. A 1986 report demonstrated that the organs most frequently damaged by ethanol abuse, 
notably pancreas and liver, were found to have the highest levels of fatty acid ethyl esters and the enzymes responsible for their synthesis in patients who died while intoxicated with ethanol (Laposata and Lange, 1986). A technical development which has spurred the study of FAEE in vitro and in vivo was the solubilization (in aqueous medium) of FAEE in the core of isolated human low density lipoprotein (LDL) particles, previously delipidated to remove the core trigylceride and cholesterol ester (Bird et al., 1995). Another was the use of gas chromatography-mass spectrometry (GC-MS) for the quantitation of FAEE for conclusive identification (Laposata et al., 1995; Zybko et al., 2001).

Toxicity of FAEE. Initial studies on the toxicity of FAEE involved the use of HepG2 cells incubated with either native low density lipoprotein or low density lipoprotein reconstituted with FAEE. The addition to the medium of particles containing FAEE resulted in decreased $\left[{ }^{3} \mathrm{H}\right]$ thymidine incorporation into the cells, as well as decreased ${ }^{35} \mathrm{~S}$-methionine incorporation into cellular protein (Szczepiorkowski et al., 1995). The concentrations of FAEE used in these studies which produced these toxic effects in liver-derived HepG2 cells was $100-200 \mu \mathrm{M}$ and above. Plasma concentrations of FAEE up to $41 \mu \mathrm{M}$ are found in chronic alcoholics; for this reason, an in vivo study with rats was performed using $11 \mu \mathrm{M}$ FAEE, a concentration easily attainable by ethanol consumption, and damage to both liver and pancreas was assessed (Werner et al., 1997). In this in vivo study, LDL reconstituted with either cholesterol ester or with FAEE was infused into rats as an intra-arterial bolus with an additional $3 \mathrm{hr}$ of infusion. Rats receiving FAEE-laden lipoproteins showed pancreatic damage and the rats receiving non-FAEE containing lipoproteins showed no injury. There was no evidence of liver damage in either group, suggesting that the pancreas is more susceptible to injury by FAEE from a single exposure than is the liver. Studies in which multiple inhibitors of oxidative ethanol metabolism have been added to cultured cells and administered in vivo to animals exposed to ethanol have been performed, and in both cases there was an increase in FAEE (Werner et al., 2001). This demonstrated that there is a linkage between the oxidative and nonoxidative pathways of ethanol metabolism, whereby a blockage of the oxidative pathway results in increased flux through the nonoxidative pathway. There was also a corresponding increase pancreatic damage in the in vivo study further supporting the conclusion that FAEE can induce cell injury.

FAEE Synthesis. The HepG2 cell model has been utilized to study the synthesis of FAEE (Kabakibi et al., 1998). These cells produce FAEE when incubated with ethanol at physiologic concentrations. The production of FAEE can be assessed by the measurement of FAEE in the cells, and secretion of FAEE can be assessed by the quantitation of FAEE in the medium. Our data have led us to propose a mechanism for the synthesis and transport of FAEE within HepG2 cells which involves the synthesis of the FAEE molecule in the microsomes of the cell, subsequent binding to fatty acid binding protein (FABP), and movement of the FAEE to the plasma membrane. At this point, the FAEE are removed from the cell by lipoproteins and albumin for transport in the circulation. Numerous studies have been performed to determine the source of the fatty acid within the cell for FAEE synthesis. Thus far, addition of all fatty acids except for palmitate to the extracellular medium results in an increase in the production of FAEE in HepG2 cells, with the added fatty acid as prominent among those found in FAEE (Dan and Laposata, 1997). Furthermore, the fatty acids which are most newly incorporated into cells are preferred for FAEE synthesis over those fatty acids which have been in the cells for longer periods of time (Dan and Laposata, 1998). White blood cells, particularly the natural killer (NK) cells, contain measurable amounts of FAEE synthetic enzymes (Gorski et al., 1996). Using white blood cell FAEE synthetic activity (which one does not need a liver or pancreatic biopsy to obtain), it has been demonstrated that the enzymes for FAEE synthesis are induced by up to 6 days of daily intake of ethanol, but with continued ethanol intake, the enzyme activity decreases to below baseline levels. Chronic alcoholics have lower FAEE synthase activity in their white blood cells than nonalcoholics. In a separate set of experiments, purified FAEE synthase was shown to have a synthetic capacity for cocaethylene, a metabolite of cocaine (Heith et al., 1995). Patients who have abnormalities in liver or pancreatic function, reflective of injury to these organs, also release FAEE synthetic activity into the circulating blood (Al-Eryani et al., 1996). Thus, it is suspected that with liver damage, FAEE synthesis does not only occur in solid organs and intact cells, but also in the plasma secondary to the release of the cytoplasmic FAEE synthetic activity from damaged hepatocytes, and possibly pancreatic acinar cells, into the blood.

FAEE Secretion. Addition of lipoproteins or albumin to the culture medium of HepG2 cells stimulates FAEE secretion when the cells are exposed to ethanol (Hasaba and Laposata, 2001). Albumin does not result in an increase in FAEE synthesis in the cells, but does induce a redistribution of FAEE from the cells to the extracellular medium. Both HDL and LDL, however, induce a redistribution to the extracellular medium and also stimulate the cells to produce more FAEE. The FAEE species which are secreted into the blood are different from the FAEE which are present within the organs exposed to ethanol, suggesting some selectivity among FAEE molecules for release from the cell (Dan and Laposata, 1998). Also, the fatty acid composition of the FAEE in the blood is different from the fatty acid composition of the FAEE in the liver, which is presumably the major site of origin of plasma FAEE. Similarly, the fatty acid composition of FAEE differs between pancreas and pancreatic secretions and the fatty acid composition of FAEE in liver and bile is also different (Laposata et al., 2000). The selective secretion of specific FAEE species may be important if certain FAEE species are more toxic than others. Such a difference in toxicity remains to be demonstrated.

FAEE Transport in the Blood. FAEE are bound to albumin of the plasma in intoxicated individuals (Doyle et al., 
1994), and free fatty acids displace ethyl ${ }^{14} \mathrm{C}$-ethyl oleate from albumin. Thus, there is rapid transfer of FAEE between phospholipid bilayers and LDL, thereby demonstrating that the exchange from a cell membrane to a circulating lipoprotein particle is efficient and rapid (Bird et al., 1996). FAEE localizes to the core of the lipoproteins, and that as the FAEE concentration increases in the blood, a higher percentage of the FAEE is found in lipoproteins relative to albumin (Bird et al., 1997).

FAEE Degradation. FAEE within the core of an LDL particle injected into rats results in the degradation of the FAEE with a half-life of only $58 \mathrm{sec}$ (Saghir et al., 1997). The degradation is caused by the cellular elements of the blood, as cell-free plasma does not produce a similar effect (Saghir et al., 2000). Also, the metabolic fate of fatty acid released from the FAEE, when degradation separates the ethanol and fatty acid moieties, depends upon the organ or tissue in which the FAEE is degraded and the metabolic pathways for that specific fatty acid (Saghir et al., 1997).

FAEE as Markers of Ethanol Intake. FAEE is detected in blood, long after ethanol has become undetectable in the circulation and is therefore a marker of ethanol intake (Doyle et al., 1996; Salem et al., 2001a). The type of alcoholic beverage ingested has no impact on the plasma FAEE levels (Soderberg et al., 1999). Even though women have higher blood ethanol levels after ethanol intake relative to men with an equivalent weight-based intake of ethanol, men develop FAEE levels that are 2-fold higher than women. Concentrations of ethyl oleate in chronic alcoholics and episodic heavy drinkers are significantly different at or near peak blood ethanol concentrations (Soderberg et al., 2001). Thus, the presence of this particular fatty acid (oleate) in the FAEE can separate chronic alcoholics and from binge drinkers. After 24 hr of alcohol abstinence, ethyl oleate was an even better differentiating marker between chronic alcoholics and binge drinkers.In studies carried out in rats, it has been shown that intake of ethanol prior to death results in the presence of FAEE in the liver and in adipose tissue, and that the presence FAEE in these sites can serve as a marker of premortem ethanol intake (Salem et al., 2001b). In a human study with 31 autopsied cases from the hospital and medical examiners office, with postmortem intervals ranging from 5 to $29 \mathrm{hr}$, blood ethanol concentration was determined but not made known to the laboratory measuring FAEE (Refaai et al., 2001). Correct identification of individuals with a detectable blood ethanol level at autopsy, chronic alcoholics with no detectable blood ethanol at autopsy and social drinkers (with a negative blood ethanol at autopsy) was possible because of the presence of FAEE in the liver. In addition, the concentration of ethyl arachidonate (a specific species of FAEE) was useful because it was found only in individuals with a detectable blood ethanol at the time of autopsy.

Summary. FAEE are ethanol metabolites that have been shown to be toxic both in vitro and in vivo. Their synthesis, secretion, and degradation has been investigated in many studies, and substantial information has been accumulated over the past decade on these metabolic pathways. The use of FAEE both in blood and in solid organs as markers of ethanol intake continues to advance.

\section{CYCLIC CHANGE IN GENE EXPRESSION WHEN RATS ARE FED ALCOHOLIC AT A CONSTANT RATE}

\section{Samuel W. French}

The blood alcohol levels (BAL) of rats fed ethanol at a constant rate intragastrically through a permanent cannula, cycle between $<100 \mathrm{mg} \%$ to $>500 \mathrm{mg} \%$ (Tsukamoto et al., 1985a). When the BAL falls the rate of ethanol elimination increases and vice versa. The daily urine alcohol levels (UAL) were measured to follow the peaks and troughs because UAL is proportionate to BAL when ethanol is fed at a constant rate (i.e., $13 \mathrm{~g} / \mathrm{kg} /$ day). The rationale for studying this intriguing phenomenon is that the amplitude of the oscillation correlates with the worsening of the liver pathology (Tsukamoto et al., 1985b). The study of this phenomenon has provided two important observations which are reported here. 1) The cycling of the elimination rate of blood alcohol requires oscillation of the metabolic rate which is regulated by the change in thyroid hormone levels. The hormone levels are driven by changes in the body temperature induced by the fluctuations in BAL ( $\mathrm{Li}$ et al., 2001a). The cycle is prevented by giving propylthiouracil, cutting the pituitary stalk or feeding T4. T4 treatment prevents the alcohol-induced liver pathology but causes submassive necrosis and fibrosis in the ethanol-fed rats (Li et al., 2001b). 2) Gene expression fluctuates during the cycle in a way that is similar to the ischemia/reperfusion model of liver injury.

With regards to the first observation, the severity of the pathology was greater at the peaks of the cycle. The serum LPS levels were greater at the peaks but $\mathrm{TNF} \alpha$ levels were similarly elevated at both the peaks and troughs of the cycle. ALT levels were greater at the troughs indicating that necrosis was greater at the troughs. The pattern of liver injury at the peaks and troughs was consistent with hypoxic injury at the peaks and reperfusion injury at the troughs. The evidence for hypoxic injury was that the liver ATP levels were markedly reduced at the peaks but not at the troughs (French , 2000). NADH/NAD levels were markedly increased at the peaks but not at the troughs. This was because $0_{2}$ is required to regenerate NAD from NADH in the electron transport chain in the mitochondria. The hypoxyprobe immunofluorescent method of measuring hypoxia in vivo in the liver (Arteel et al., 1996) showed that the livers were hypoxic at the peaks but not at the troughs.

The genes expression patterns vary during the UAL cycle, depending on the particular gene. The expression is up-regulated, down-regulated or unchanged at the UAL peaks and troughs compared with controls (Shahed et al., 2001, French , 2000). When genes regulated by the HIF-1 $\alpha$ transcription factor were measured by RT PCR, vascular endothelial growth factor (VEGF) was up-regulated at both the peaks and troughs compared to controls. Western 
blot analysis done by using an antibody to VEGF showed an increase in protein only at the peaks when hypoxia of the liver was manifested. Another gene, erythropoietin, which is up-regulated by hypoxia, was up-regulated only at the peaks. Hemoxygenase, a third hypoxia regulated gene was not changed.

Oxidative stress related genes such as CYP2El, iNOS and COX-2 were variously expressed at the peaks and troughs of the UAL cycle. CYP2E1 was up-regulated at the peaks and troughs as assessed by RT-PCR. CYP2E1 was upregulated only at the peaks when Northern blots and microarray gene analysis were done. Inducible NO synthase (iNOS), a mitochondrial protein was down-regulated at the troughs. Immunofluorescence of liver sections at the troughs showed loss of mitochondrial iNOS in the centrilobular hepatocytes. Thus the protective role of NO as an antioxidant may have been reduced at the troughs.

The gene expression of cytokines ( $\mathrm{TNF} \alpha)$ and chemokines (MCP-1) were also differentially altered at the peaks and troughs. Although TNF $\alpha$ was not changed, MCP-1 was upregulated at the peaks compared to the troughs. This could be one factor which mediated the inflammation seen in livers at the peaks. MCP-1 production was increased by blood monocytes of patients during alcoholic hepatitis (Devalaraja et al., 1999).

The expression of apoptotic-associated genes BAX, Bc12, FAS and FASL were measured but only BAX was upregulated at the troughs compared with the peaks and controls. This was associated with an increase in apoptosis seen in livers at the troughs which were stained using TUNEL.

The gene expression of growth factors were also differentially changed at the peaks and troughs. Connective tissue growth factor (CTGF) was up-regulated at both the peaks and troughs. CTGF is involved in hepatocellular carcinoma formation (Hirasaki et al., 2001). The Western blot using c-fos antibody showed an increase at the troughs compared to controls and peaks. Microarray gene analysis showed that IGF-1 was increased at the troughs compared with the peaks. JUN was increased at troughs compared to the peaks. Thus gene expression upregulation which supports liver cell regeneration was found at the troughs.

Genes up-regulated at the peaks compared to the troughs found on microarray gene analysis were as follows (French , 2000); MAP kinase 3, DNA-damage-inducible protein 45, D-amino acid oxidase, catechol-O-methyl transferase, tyrosine, phosphatase-like protein, fatty acid synthetase and fatty acid binding protein in liver. Cytochrome $\mathrm{P}-450$ isozymes and reductases and $\mathrm{ADH}$ isozymes were up-regulated at the peaks as follows: P-450 2A1, CYP450 14 DM, CYP11A1, ADH-1, NADH-cyto b5 reductase and NADPH-CYP450 reductase.

In summary, changes in gene expression are different at high and low UAL during the cycle. Many are increased during the peaks when hypoxia and a shift in the NADH/ NAD redox state exists. Other genes involved in growth, apoptosis and mitochondrial antioxidant activity are in- creased at the troughs of the UAL cycle, when reperfusionlike injury occurs. It is important to control for the influence of BAL on gene expression when studying experimental alcoholic liver disease ( $\mathrm{Li}, 2002)$.

\section{REFERENCES}

Adachi Y, Bradford BU, Gao W, Bojes HK, Thurman RG (1994) Inactivation of Kupffer cells prevents early alcohol-induced liver injury. Hepatology 20:453-460.

Adachi Y, Moore LE, Bradford BU, Gao W, Thurman RG (1995) Antibiotics prevent liver injury in rats following long-term exposure to ethanol. Gastroenterology 108:218-224.

Al-Eryani S, Kabakibi A, Cluette-Brown JE, Laposata M (1996) Fatty acid ethyl ester synthase, an enzyme for nonoxidative ethanol metabolism is present in serum after liver and pancreatic injury. Clin Chem 42:24-27.

Arteel GE, Raleigh JA, Bradford Bu, Thurman RG (1996) Acute alcohol produces hypoxia directly in rat liver tissue in vivo: role of Kupffer cells. Am J Physiol 271:G494-G500.

Beg A, Baltimore D (1998) An essential role for NF- $\kappa$ B in preventing TNF- $\alpha$ induced cell death. Science 274:782-784.

Bellezzo JM, Britton RS, Bacon BR, Fox ES (1996) LPS-mediated NFkappa beta activation in rat Kupffer cells can be induced independently of CD14. Am J Physiol 270:G956-961.

Bird DA, Szczepiorkowski ZM, Trace VC, Laposata M (1995) Lowdensity lipoprotein reconstituted with fatty acid ethyl esters as a physiological vehicle for ethyl ester delivery to intact cells. Alcohol Clin Exp Res 19:1265-1269.

Bird DA, Laposata M, Hamilton JA (1996) Binding of ethyl oleate to low density lipoprotein, phospholipid vesicles, and albumin: ${ }^{13} \mathrm{C}$ NMR study. J Lipid Res 37:1449-1458.

Bird DA, Kabakibi A, Laposata M (1997) The distribution of fatty acid ethyl esters among lipoproteins and albumin in human serum. Alcohol Clin Exp Res 21:602-605.

Dan L, Laposata M (1997) Ethyl palmitate and ethyl oleate are the predominant fatty acid ethyl esters in the blood after ethanol ingestion and their synthesis is differentially influenced by the extracellular concentrations of their corresponding fatty acids. Alcohol Clin Exp Res 21:292-296.

Dan L, Laposata M (1998) Quantitation of the mass of fatty acid ethyl esters synthesized by HepG2 cells incubated with ethanol. Alcohol Clin Exp Res 22:1125-1131.

Devalaraja MN, McClain CJ, Barve S, Vaddi K, Hill D (1999) Increased monocyte MCP-1 production in acute alcoholic hepatitis. Cytochrome 11:875-881.

Dinchuk JE, Car BD, Focht RJ, Johnston JJ, Jaffee BD, Covington MB, Contel NR, Eng VM, Collins RJ, Czerniak PM, et al. (1995) Renal abnormalities and an altered inflammatory response in mice lacking cyclooxygenase II. Nature 378:406-409.

Doyle KM, Bird D, Al-Salihi S, Hallaq Y, Cluette-Brown JE, Goss KA, Laposata M (1994) Fatty acid ethyl esters are present in human serum following ethanol ingestion. J Lipid Res 35:428-437.

Doyle KM, Cluette-Brown JE, Dube DM, Bernhardt TG, Morse CR, Laposata M (1996) Fatty acid ethyl esters in the blood as markers for ethanol intake. JAMA 276:1152-1156.

Felver ME, Mezey E, McGuire M, Mitchell MC, Herlong HF, Veech GA, Veech RL (1990) Plasma tumor necrosis factor-alpha predicts decreased long term survival in severe alcoholic hepatitis. Alcohol Clin Exp Res 14:255-259.

French BA (2000) Hypoxia reperfusion liver injury in an alcohol binge drinking model (abstract). Hepatology 32:410.

Gorski NP, Nouraldin H, Dube DM, Preffer FI, Dombkowski DM, Villa EM, Lewandrowski KB, Laposata M (1996) Reduced fatty acid ethyl ester synthase activity in the white blood cells of alcoholics. Alcohol Clin Exp Res 20:268-274.

Hailman E, Lichenstein HS, Wurfel MM, Miller DS, Johnson DA, Kelley M, Busse LA, Zukowski MM, Wright SD (1994) Lipopolysaccharide 
(LPS)-binding protein accelerates the binding of LPS to CD14. J Exp Med 179:269-277.

Hasaba A, Laposata M (2001) The synthesis and secretion of fatty acid ethyl esters from HepG2 cells are stimulated by lipoproteins and albumin. Alcohol Clin Exp Res 25:338-343.

Heith AM, Morse CR, Tsujita T, Volpacelli SA, Flood JG, Laposata M (1995) Fatty acid ethyl ester synthase catalyzes the esterification of ethanol to cocaine. Biochem Biophys Res Commun 208:549-554.

Hill DB, Barve S, Barve SJ, McClain CJ (2000) Increased monocyte nuclear factor kappa B and tumor necrosis factor production in alcoholic hepatitis. J Lab Clin Med 135:387-395.

Hirasaki S, Koide N, Ujike K, Shinji T, Tsuji T (2001) Expression of Nov, CYR61 and CTGF genes in human hepatocellular carcinomas. Hepatol Res 19:294-305.

Iimuro Y, Gallucci RM, Luster MI, Kono H, Thurman RG (1997) Antibodies to tumor necrosis factor alfa attenuate hepatic necrosis and inflammation caused by chronic exposure to ethanol in the rat. Hepatology 26:1530-1537.

Kabakibi A, Morse CR, Laposata M (1998) Fatty acid ethyl esters and HepG2 cells: intracellular synthesis and release from the cells. J Lipid Res 39:1568-1582.

Laposata EA, Lange LG (1986) Presence of nonoxidative ethanol metabolism in human organs commonly damaged by ethanol abuse. Science 231:497-499.

Laposata M, Szczepiorkowski ZM, Cluette-Brown JE (1995) Fatty acid ethyl esters: Nonoxidative metabolites of ethanol. Prostaglandins Leukot Essent Fatty Acids 52:87-91.

Laposata M, Kabakibi A, Walden MP, Cluette-Brown JE, Nanji AA, Refaai MA, Werner J, Nanji AA (2000) Differences in the fatty acid composition of fatty acid ethyl esters in organs and their secretions. Alcohol Clin Exp Res 24:1488-1491.

Li J, French BA, Fu P, French SW (2001a) Thyroid hormone causes liver necrosis in rats fed ethanol intragastrically. Exp Mol Pathol 71:79-88.

Li J, French BA, Riley N, Bardag-Gorce F, Fu P, French SW (2001b) Oral low-carbohydrate alcohol liquid diet induces experimental steatohepatitis in the rat. Exp Mol Pathol 71:132-136.

Li J, Nguyen V, French BA, Parlow AF, Su GL, Fu P, Yuan QX, French SW (2000) Mechanism of the alcohol cyclic pattern: Role of the hypothalamic-pituitary-thyroid axis. Am J Physiol Gastrointest Liver Physiol 279:G118-125.

Lichtman SN, Wang J, Lemasters JJ (1998) LPS receptor CD14 participates in release of TNF-alpha in RAW 264.7 and peritoneal cells but not in Kupffer cells. Am J Physiol 275:G39-46.

Nanji AA, Khettry U, Sadrzady SM, Yamanaka T (1993) Severity of liver injury in experimental alcoholic liver disease. Correlation with plasma endotoxin, prostaglandin E2, leukotriene B4, and thromboxane B2. Am J Pathol 142:367-373.

Nanji AA, Khettry U, Sadrazdeh SM (1994) Lactobacillus feeding reduces endotoxemia and severity of experimental alcoholic liver (disease). Proc Soc Exp Biol Med 205:243-247.

Nanji AA, Miao L, Thomas P, Rahemtulla A, Khwaja S, Zhoa S, Peters D, Tahan SR, Dannenberg AJ (1997) Enhanced cyclooxygenase-2 expression in alcoholic liver disease in the rat. Gastroenterolgoy 112:943-951.

Nanji AA, Jokelainen K, Rahemtulla A, Miao L, Fogt F, Matsumoto M, Tahan SR, Su GL (1999) Activation of nuclear factor kappa B and cytokine imbalance in experimental alcoholic liver disease in the rat. Hepatology 30:934-943.

Nanji AA, Jokelainen K, Fotouhinia M, Rahemtulla A, Thomas P, Tipoe GL, Su GL, Dannenberg AJ (2001) Increased severity of alcoholic liver injury in female rats: Role of oxidative stress, endotoxin and chemokines. Am J Physiol Gastrointest Liver Physiol 281:G1348-56

Refaai MA, Nguyen PN, Steffensen TS, Evans RJ, Cluette-Brown JE, Laposata M (2001) Liver and adipose tissue fatty acid ethyl esters obtained at autopsy are postmortem markers for premortem ethanol intake. Clin Chem 48:77-83.

Saghir M, Werner J, Laposata M (1997) Rapid in vivo hydrolysis of fatty acid ethyl esters, toxic nonoxidative ethanol metabolites. Am J Physiol Gastrointest Liver Physiol 273(1 Pt 1):G184-190.
Saghir M, Werner J, Laposata M (2000) A comparison of the hydrolysis and metabolism in rats of fatty acid ethyl esters within human lowdensity lipoproteins. Res Commun Alcohol Subst Abuse 20:123-134.

Salem RO, Cluette-Brown JE, Hasaba A, Laposata M (2001a) The effect of specimen anticoagulant and storage on serum and plasma fatty acid ethyl ester concentration measurements. Clin Chem 47:126-127.

Salem RO, Refaai MA, Cluette-Brown JE, Russo JW, Laposata M (2001b) Fatty acid ethyl esters in liver and adipose tissues as post mortem markers for ethanol intake. Clin Chem 47:722-725.

Schumann RR, Leong SR, Flaggs GW, Gray PW, Wright SD, Mathison JC, Tobias PS, Ulevitch RJ (1990) Structure and function of lipopolysaccharide binding protein. Science 249:1429-1431.

Shahed AR, Li J, Yuan QX, French SW (2001) Effect of ethanol cycling on gene expression in intragastric ethanol feeding rat model of alcohol liver disease. FASEB J 15:A609.

Soderberg BL, Sicinska ET, Blodget E, Cluette-Brown JE, Suter PM, Schuppisser T, Vetter W, Laposata M (1999) Preanalytical variables affecting the quantification of fatty acid ethyl esters in plasma and serum samples. Clin Chem 45:2183-2190.

Soderberg BL, Sicinska ET, Best CA, Walden MP, Blodget E, CluetteBrown JE, Laposata M (2001) The diagnosis of chronic alcoholism by the fatty acid composition of fatty acid ethyl esters (Abstract). Alcohol Clin Exp Res 25:136A.

Su G, Goyert S, Fan M, Aminlari A, Gong K, Klein R, Myc A, Alarcon W, Remick D, Wang S (2002) Activation of human and mouse Kupffer cells by lipopolysaccharide is mediated by CD14. Am J Physiol, in press.

Su G, Klein R, Aminlari A, Zhang H, Steinstraesser L, Alarcon W, Remick D, Wang S (2000) Kupffer cell activation by lipopolysaccharide in rats: role for lipopolysaccharide binding protein and toll-like receptor 4. Hepatology 31:932-936.

Su G, Rahemtulla A, Thomas P, Klein R, Wang S, Nanji A (1998) CD14 and lipopolysaccharide binding protein expression in a rat model of alcoholic liver disease. Am J Pathol 1998 Mar;152(3):841-849.

Szczepiorkowski ZM, Dickerson GR, Laposata M (1995) Fatty acid ethyl esters in reconstituted low density lipoproteins are toxic for intact HepG2 cells. Gastroenterology 108:515-522.

Takai N, Kataoka M, Higuchi Y, Matsuura K, Yamamoto S (1997) Primary structure of rat CD14 and characteristics of rat CD14, cytokine, and NO synthase mRNA expression in mononuclear phagocyte system cells in response to LPS. J Leukoc Biol 61:736-744.

Tsukamoto H, French SW, Largman C (1985a) Correlation of cyclic pattern of blood alcohol levels with progression of alcoholic liver injury. Biochern Arch 1:215-220.

Tsukamoto H, French SW, Reidelberger RD, Largman C (1985b) Cyclic pattern of blood alcohol levels during continuous intragastric infusion in rats. Alcohol Clin Exp Res 9:31-37.

Werner J, Laposata M, Fernandez-del Castillo C, Saghir M, Iozzo RV, Lewandrowski KB, Warshaw AL (1997) Pancreatic injury induced by fatty acid ethyl ester, a nonoxidative metabolite of alcohol. Gastroenterology 113:286-294.

Werner J, Saghir M, Fernandez-del Castillo C, Warshaw AL, Laposata M (2001) Linkage of oxidative and non-oxidative ethanol metabolism in the pancreas and toxicity of non-oxidative ethanol metabolites for pancreatic acinar cells. Surgery 129:736-744.

Wright SD, Ramos RA, Tobias PS, Ulevitch RJ, Mathison JC (1990) CD14, a receptor for complexes of lipopolysaccharide (LPS) and LPS binding protein [see comments]. Science 249:1431-1433.

Yin M, Wheeler MD, Kono H, Bradford BU, Gallucci RM, Luster MI, Thurman RG (1999) Essential role of tumor necrosis factor alpha in alcohol-induced liver injury in mice. Gastroenterology 117:942-952.

Ziegler-Heitbrock H, Ulevitch RJ (1993) CD14: cell surface receptor and differentiation marker. Immunology Today 14:121-125.

Zybko WC, Cluette-Brown JE, Laposata M (2001) Improved sensitivity and reduced sample size in serum fatty acid ethyl ester analysis. Clin Chem 47:1120-1121. 